\title{
ScienceDirect
}

Special Issue on Raw Materials and Recycling

\section{Production of thermoplastics matrix preimpregnated materials to manufacture composite pultruded profiles}

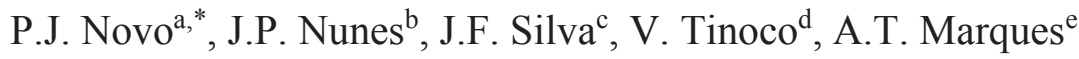 \\ ${ }^{a}$ School of Tech. and Management, Polytechnic Institute of Leiria, 2411-901 Leiria, Portugal \\ ${ }^{b}$ Institute of Polymers and Composites/I3N, Minho University, 4800-058 Guimaraes, Portugal \\ ${ }^{c}$ Dep. of Mechanical Engineering ISEP, 4200-072 Porto, Portugal \\ ${ }^{d}$ Department of Polymer Engineering, Minho University, 4800-058 Guimaraes, Portugal \\ ${ }^{e}$ DEMEGI / FEUP, 4200-465 Porto, Portugal
}

\begin{abstract}
The aim of this work is to optimize the production of new continuous carbon fibers reinforced polypropylene matrix pre-impregnated materials (towpregs) continuously processed by dry deposition of polypropylene (PP) powder by our own developed dry coating line. The processing of the produced towpregs by pultrusion, using a prototype equipment, was also optimized. The optimization of both processes was made by studying the influence of the most relevant processing parameters in the final properties of the produced towpregs and composites. The method of Taguchi/DOE (Design of Experiments) was used to allow the determination of the optimal processing windows. The possibility of using maleic anhydride as compatibilizer for polypropylene reinforced carbon fiber composites (CF/PP) was also analyzed. A pre-consolidate tape was produced by the melting cross-head extrusion process and its proprieties compared with those of towpregs. Finally, towpregs were characterized by scanning electron microscopy (SEM) and visual analysis. Their polymer mass contents were determined and the final pultruded composite profiles were also submitted to tensile, interlaminar, flexural, calcination and optical microscopy tests.
\end{abstract}

(C) 2013 Sociedade Portuguesa de Materiais (SPM). Published by Elsevier España, S.L. All rights reserved.

Keywords: towpreg; composite materials; thermoplastic; pultrusion; polypropylene; Taguchi/DOE.

This paper was presented at MATERIAIS 2013, Coimbra, Portugal, March 25-27, 2013

\section{Introduction}

During the last decades, composites have successfully replaced traditional materials in many engineering applications due to its excellent properties, mainly their excellent mechanical properties combined with low density $[1,2]$.

Although only recently thermoplastic matrices have been used in long and continuous fiber reinforced

\footnotetext{
* Corresponding author.

E-mail address: paulo.novo@ipleiria.pt (P.J. Novo)
}

composites replacing with success thermosetting matrices, the number of their applications is increasing due to their better ecological and mechanical performance. Composites with thermoplastic matrices offers increased fracture toughness, higher impact tolerance, short processing cycle time and excellent environmental stability. They are recyclable, postformable and can be joined by welding. The use of long/continuous fiber reinforced thermoplastic matrix composites involves, however, great technological and scientific challenges since thermoplastics present much higher viscosity than thermosettings, which makes much difficult and complex the impregnation of reinforcements and consolidation tasks [2-8]. 
Today, two major technologies are being used to allow wet reinforcing fibers with thermoplastic polymers [58]: i) the direct melting of the polymer and, ii) the intimate fiber/matrix contact prior to final composite fabrication. Continuous fiber reinforced thermoplastic matrix pre-impregnated tapes (PCT's) are, for example, produced by direct melting processes. Alternatively, intimate contact processes allow producing cheap and promising pre-impregnated materials, such as, commingled fibers, co-woven fabrics and powder coated towpregs.

Sometimes, thermoplastic compatibilizers were added to the matrices to improve their adhesion and facilitate impregnation to reinforcements [9].

\section{Experimental}

\subsection{Raw materials}

The following raw materials were used to produce $\mathrm{CF} / \mathrm{PP}$ pre-impregnated materials for this work: i) a PP powder ICORENE 9184B ${ }^{\circledR}$ and carbon fiber roving $\mathrm{M} 30 \mathrm{SC}^{\mathbb{B}}$ from the ICO Polymers and TORAY, respectively, were used to produce the CF/PP towpregs (Fig. 1a), ii) PP powder Moplen RP348U ${ }^{\circledR}$ from Basell and the carbon fiber roving already mentioned were used to manufacture the CF/PP tapes (Fig. 1b). Tables 1 and 2 present the properties of these raw-materials.

Some batches of CF/PP towpregs were also produced using PP powder (ICORENE 9184B P ${ }^{\circledR}$ ) additivated with $1 \%$ in mass content of maleic anhydride, S $4729608707^{\circledR}$ from Merck Schuchardt OHG, in order to assess the possible enhancement of fiber/matrix adhesion [9-13].

Table 1. Properties of CF/PP towpregs raw-materials

\begin{tabular}{|c|c|c|c|c|}
\hline \multirow{2}{*}{ Property } & \multicolumn{2}{|c|}{$\begin{array}{c}\text { PP powder } \\
\left(\text { ICORENE 9184B } \mathrm{P}^{\circledR}\right)\end{array}$} & \multicolumn{2}{|c|}{$\begin{array}{c}\text { Carbon fiber } \\
\left(\text { TORAY M30 SC }{ }^{\circledR}\right)\end{array}$} \\
\hline & $\begin{array}{c}\text { Manufacturer } \\
\text { datasheet }\end{array}$ & Experimental & $\begin{array}{c}\text { Manufacturer } \\
\text { datasheet }\end{array}$ & $\begin{array}{l}\text { Typical } \\
\text { values }\end{array}$ \\
\hline $\begin{array}{l}\text { Linear density } \\
(\mathrm{Tex})\end{array}$ & - & - & 760 & - \\
\hline $\begin{array}{l}\text { Specific gravity } \\
\left(\mathrm{Mg} / \mathrm{m}^{3}\right)\end{array}$ & 0.91 & 0.91 & 1.73 & 1.75 \\
\hline $\begin{array}{l}\text { Tensile strength } \\
\text { (MPa) }\end{array}$ & $30^{1}$ & $19^{1}$ & 5490 & 2600 \\
\hline $\begin{array}{l}\text { Young Modulus } \\
(\mathrm{GPa})\end{array}$ & 1.3 & 0.98 & 294 & 170 \\
\hline Poisson's ratio & - & 0.21 & - & - \\
\hline $\begin{array}{l}\text { Average powder } \\
\text { particle size } \\
(\mu \mathrm{m})\end{array}$ & 440 & 163 & - & - \\
\hline
\end{tabular}

Table 2. Properties of the raw-materials used to produce $\mathrm{CF} / \mathrm{PP}$ tapes accordingly to manufacturers datasheets

\begin{tabular}{lcc}
\hline \multicolumn{1}{c}{ Property } & $\begin{array}{c}\text { PP granules } \\
\left(\text { Moplen RP348U }{ }^{\circledR} \text { from Basell) }\right.\end{array}$ & $\begin{array}{c}\text { Carbon fiber roving } \\
\left(\mathrm{M} 30 \mathrm{SC}^{\circledR}\right.\end{array}$ \\
\hline $\begin{array}{l}\text { Linear density } \\
(\mathrm{Tex})\end{array}$ & - & 760 \\
$\begin{array}{l}\text { Specific gravity } \\
(\mathrm{Mg} / \mathrm{m} 3)\end{array}$ & 900 & 1.73 \\
$\begin{array}{l}\text { Tensile strength } \\
(\mathrm{MPa})\end{array}$ & $30^{\mathrm{a}}$ & 5490 \\
$\begin{array}{l}\text { Young Modulus } \\
(\mathrm{GPa})\end{array}$ & 1.1 & 294 \\
\hline${ }^{\mathrm{a}}$ Yield Strength & & \\
\end{tabular}

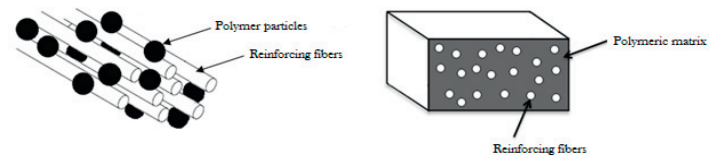

$\begin{array}{ll}\text { a) towpregs } & \text { b) Pre-consolidated tapes (PCT's) }\end{array}$

Fig. 1. CF/PP pre-impregnated products under study.

\subsection{Production of Thermoplastic Matrix Pre-Impregnated Products}

\subsubsection{Production of towpregs}

The CF/PP towpregs were produced in a dry powder coating equipment schematically shown in Fig. 2 $[14,15]$. It consists of six main parts: wind-off system, fiber spreader unit, heating section, coating section, consolidation unit and a wind-up section. Initially, the reinforcing fibers are wound-off and pulled through a pneumatic spreader and then coated with polymer by heating in a convection oven and made to pass into a polymer powder vibrating bath. A gravity system allows maintaining the amount of polymer powder constant. The consolidation unit oven allows softening the polymer powder, promoting its adhesion to the fiber surface. Finally, the thermoplastic matrix towpreg is cooled down and wound-up on a spool.

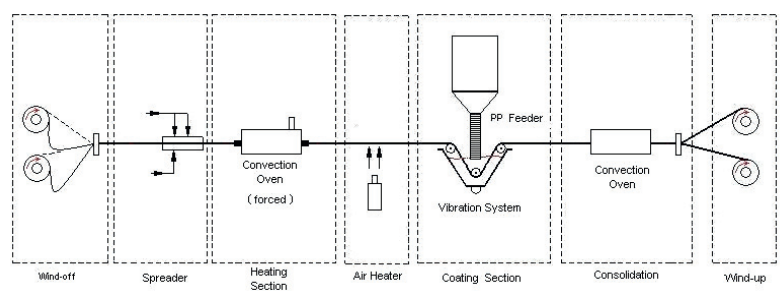

Fig. 2. Powder coating line setup. 


\subsubsection{Towpreg production optimization}

In order to optimize the production of $\mathrm{CF} / \mathrm{PP}$ powder coated towpregs, different processing variables combinations were experimented and the number of trials optimized using the Taguchi approach. The studied operational parameters were:

- heating oven temperature $\left(600,650\right.$ and $\left.700{ }^{\circ} \mathrm{C}\right)$;

- consolidation oven temperature (350, 400 and $\left.450{ }^{\circ} \mathrm{C}\right)$;

- linear pull speed (4, 6 and $8 \mathrm{~m} / \mathrm{min})$.

The Taguchi approach was applied to the towpregs production process in order to obtain the condition that maximizes polymer powder content.

The polymer mass fraction in the towpregs, $\omega_{\mathrm{p}}$, was determined by weighting towpreg strips produced in those different conditions, using the following equation:

$$
\omega_{p}=\frac{W_{t}-W_{f}}{W_{t}}
$$

where $\mathrm{W}_{\mathrm{t}}$ and $\mathrm{W}_{\mathrm{f}}$ are the measured unit length weights of the towpreg strip and fiber roving, respectively.

Table 3 shows the used processing conditions and obtained results, according to the established design of experiments. The average polymer mass content in towpregs, established by the design of experiences was $34.5 \%$ (Table 3 ).

Table 3. Taguchi approach applied to towpregs manufacturing process

\begin{tabular}{ccccc}
\hline & \multicolumn{3}{c}{ Processing variables } & Results: \\
\cline { 2 - 4 } Experiments & $\begin{array}{c}\text { Heating } \\
\text { oven } \\
\text { temperature } \\
\left({ }^{\circ} \mathbf{C}\right)\end{array}$ & $\begin{array}{c}\text { Consolidation } \\
\text { furnace } \\
\text { temperature } \\
\left({ }^{\circ} \mathbf{C}\right)\end{array}$ & $\begin{array}{c}\text { Linear } \\
\text { pulling speed } \\
(\mathbf{m} / \mathbf{m i n})\end{array}$ & $\begin{array}{c}\text { Polymer mass } \\
\text { fraction } \\
(\%)\end{array}$ \\
\hline 1 & 600 & 350 & 4 & 32.2 \\
2 & 600 & 400 & 6 & 31.4 \\
3 & 600 & 420 & 8 & 20.6 \\
4 & 650 & 350 & 8 & 27.9 \\
5 & 650 & 400 & 4 & 39.9 \\
6 & 650 & 420 & 6 & 40.7 \\
7 & 700 & 350 & 6 & 35.6 \\
8 & 700 & 400 & 8 & 40.6 \\
9 & 700 & 420 & 4 & 40.4 \\
\hline
\end{tabular}

The mains effects of the processing variables on the results can be seen from Fig. 3 .

The optimal condition obtained from Taguchi method application led to the following operating parameters selection: heating oven temperature and consolidation oven temperatures of $700{ }^{\circ} \mathrm{C}$ and $400^{\circ} \mathrm{C}$ respectively, and a linear pulling speed of $4 \mathrm{~m} / \mathrm{min}$. Using this optimal operative condition, the amount of polymer should increased up to $45.6 \%$. However, the operative condition that has chosen as optimal had a line pull speed of $6 \mathrm{~m} / \mathrm{min}$ allowing a high rate of production, lower processing problems and sufficiently levels of polymer content $(40 \%$, enough for the of use of towpregs in the pultrusion process). Also, the addition of $1 \%$ of maleic anhydride to the PP polymer had no influence on the towpreg polymer mass fraction.
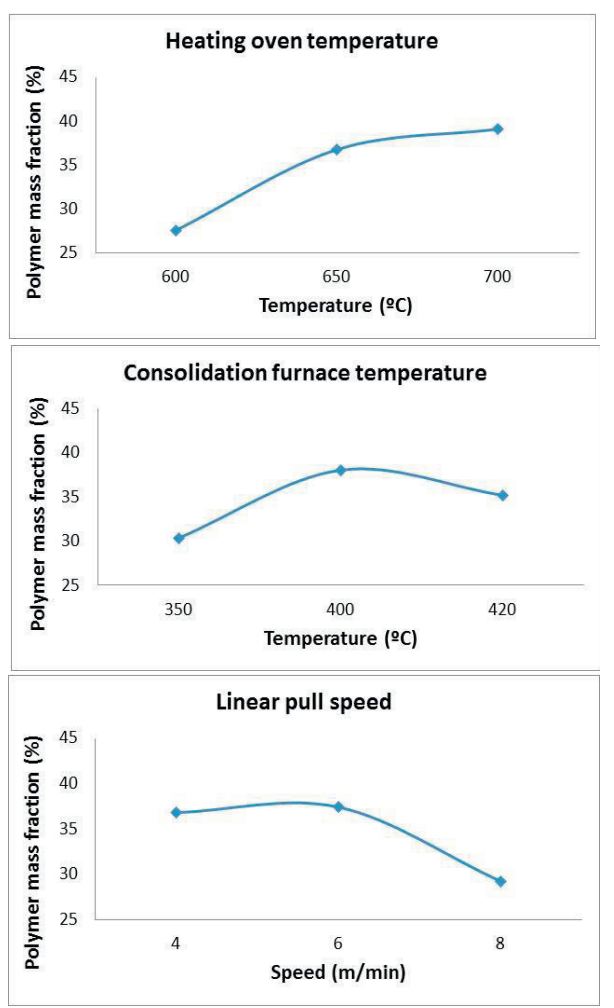

Fig. 3. Variation of towpreg polymer content with processing parameters

\subsubsection{Production of pre-consolidate tapes (PCT)}

The CF/PP PCT used in this work was produced in a cross-head extrusion equipment existing in our laboratories (see Fig. 4). The core of this technology is an impregnation unit where the carbon fibers are introduced, spread and impregnated by the polymer melt. Impregnation is achieved by pressurizing the molten polymer trapped between the unit's spreading elements and the fiber rovings.

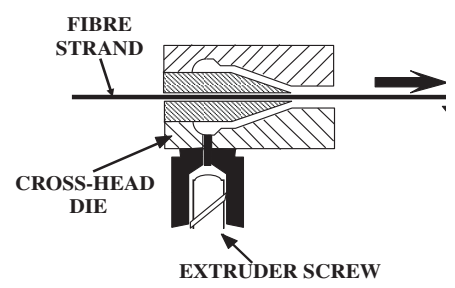

Fig. 4. Cross-head extrusion die. 
The apparatus consists of a creel holding system for fiber rovings, a guidance unit allowing an adequate transport of fiber into the impregnation section, an extruder to melt and feed the molten polymer into the impregnation unit, the impregnation unit itself and, subsequently, a cooling unit, a puller, and a take-up device where the composite tape is collected [16]. Main properties of the PCTs produced by this way are given in Table 4.

Table 4. Overview of the main properties of the produced preconsolidated tapes (PCT's)

\begin{tabular}{ll}
\hline \multicolumn{1}{c}{ Property } & \multicolumn{1}{c}{ Description } \\
\hline Fiber type & Carbon, 760 Tex \\
Filament diameter & $5 \mu \mathrm{m}$ \\
Fiber content & $45 \mathrm{wt} \%$ \\
Matrix type & Polypropylene (PP) \\
Tape width & $25 \mathrm{~mm}$ \\
Tape linear density & $14000 \mathrm{Tex}$ \\
\hline
\end{tabular}

\subsection{Processing of the pre-impregnated materials}

The CF/PP pre-impregnated materials (towpregs and PCT's) were processed into composite bar profiles using a prototype pultrusion line [16, 17].

Our developed $10 \mathrm{kN}$ pultrusion equipment, schematic depicted in Fig.5, consists in five main parts: i) an initial towpreg bobbins holding cabinet; ii) guiding system; iii) pultrusion head, that includes a pre-heating furnace and the pressurization/consolidation and cooling dies; iv) pulling system and, v) the final profile cutting system.

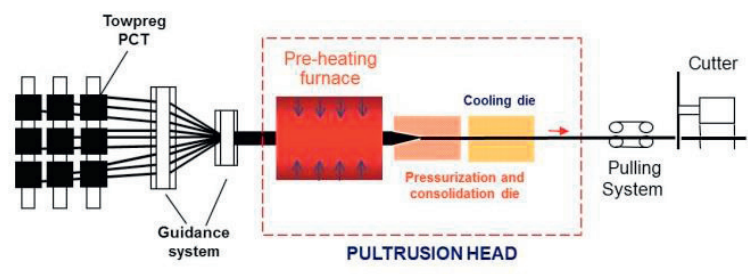

Fig. 5. Schematic diagram of the pultrusion line.

To produce composite profiles, the pre-impregnated materials are guided into the pre-heating furnace to be heated up to the required temperature. Then, they enter in the pultrusion die to be heated up and consolidated to the required size in its first zone and, after cooled down in order to solidify. The pultruded material is then cut into specified lengths.

A die with a cavity of $20 \times 2(\mathrm{~mm})$ was used to produce a composite rectangular shaped bar.

\subsubsection{Towpreg processing and optimization}

Bar profiles were manufactured by pultrusion from different towpregs, using operating conditions in order to optimize the processing. The studied processing variables were:

-Furnace temperature $\left(160\right.$ and $\left.180^{\circ} \mathrm{C}\right)$;

-Heating die temperature $\left(240\right.$ and $\left.260{ }^{\circ} \mathrm{C}\right)$;

-Linear pull-speed $(0.2$ and $0.3 \mathrm{~m} / \mathrm{min})$.

Results have shown that was not possible to produce in steady conditions pultruded profiles from towpregs at pultrusion speeds and consolidation die temperatures higher than $0.4 \mathrm{~m} / \mathrm{min}$ and $260{ }^{\circ} \mathrm{C}$, respectively. By using higher values in these two parameters the process became unsteady mainly due to reflux and accumulation of the thermoplastic polymer at the entrances of the consolidation and cooling dies, respectively.

Table 5 summarizes the flexural test results obtained with the studied processing conditions.

Table 5. Flexural testing results from towpregs

\begin{tabular}{|c|c|c|c|c|c|}
\hline \multirow[b]{2}{*}{ Exper. } & \multicolumn{3}{|c|}{ Processing variables } & \multicolumn{2}{|c|}{ Flexural properties } \\
\hline & $\begin{array}{c}\text { Furnace } \\
\text { temperature } \\
\left({ }^{\circ} \mathbf{C}\right) \\
\end{array}$ & $\begin{array}{c}\text { Heating die } \\
\text { temperature } \\
\left({ }^{\circ} \mathrm{C}\right)\end{array}$ & $\begin{array}{c}\text { Linear } \\
\text { pulling speed } \\
(\mathrm{m} / \mathrm{min})\end{array}$ & $\begin{array}{c}\text { Flexural } \\
\text { modulus } \\
(\text { GPa })\end{array}$ & $\begin{array}{c}\text { Flexural } \\
\text { strength } \\
(\mathrm{MPa}) \\
\end{array}$ \\
\hline 1 & 160 & 240 & 0.2 & $86.7 \pm 1.3$ & $229.0 \pm 7.3$ \\
\hline 2 & 180 & 240 & 0.2 & $79.5 \pm 2.0$ & $212.4 \pm 12.6$ \\
\hline 3 & 160 & 260 & 0.2 & $91.0 \pm 0.4$ & $241.2 \pm 1.6$ \\
\hline 4 & 180 & 260 & 0.2 & $85.1 \pm 1.7$ & $218.2 \pm 9.1$ \\
\hline 5 & 160 & 240 & 0.3 & $82.1 \pm 2.8$ & $241.7 \pm 13.1$ \\
\hline 6 & 180 & 240 & 0.3 & $87.5 \pm 1.9$ & $239.6 \pm 13.3$ \\
\hline 7 & 160 & 260 & 0.3 & $85.0 \pm 4.4$ & $234.5 \pm 11.5$ \\
\hline 8 & 180 & 260 & 0.3 & $83.7 \pm 2.8$ & $221.3 \pm 7.1$ \\
\hline
\end{tabular}

The variation of the flexural modulus and strength with the selected processing parameters can be seen in Figures 6 and 7.

The optimal condition concerning flexural stiffness maximization obtained led to the following operating parameters selection: furnace and heated die oven temperatures of $160^{\circ} \mathrm{C}$ and $260^{\circ} \mathrm{C}$ respectively, and a linear pulling speed of $0,2 \mathrm{~m} / \mathrm{min}$. For optimizing the flexural strength the obtained parameters combination was: furnace and heated die oven temperatures of $160^{\circ} \mathrm{C}$ and $240^{\circ} \mathrm{C}$ respectively, and a linear pulling speed of $0.3 \mathrm{~m} / \mathrm{min}$.

It is possible observe that the furnace temperature of $160^{\circ} \mathrm{C}$ lead to the better results. That could be explained by the lower polymer reflux on the entrance of the heated die. The optimal operating conditions to maximize both flexural proprieties (modulus and strength) were: furnace and heated die oven temperatures of $160^{\circ} \mathrm{C}$ and $260^{\circ} \mathrm{C}$ respectively, and a linear pulling speed of $0.2 \mathrm{~m} / \mathrm{min}$. 


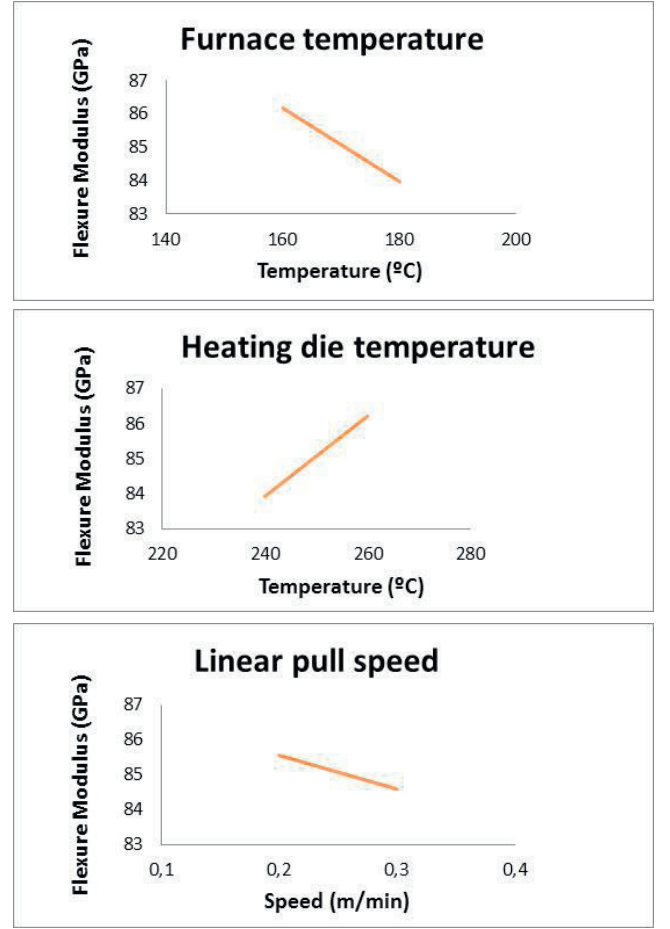

Fig. 6. Variation of the flexural modulus with the selected processing parameters.

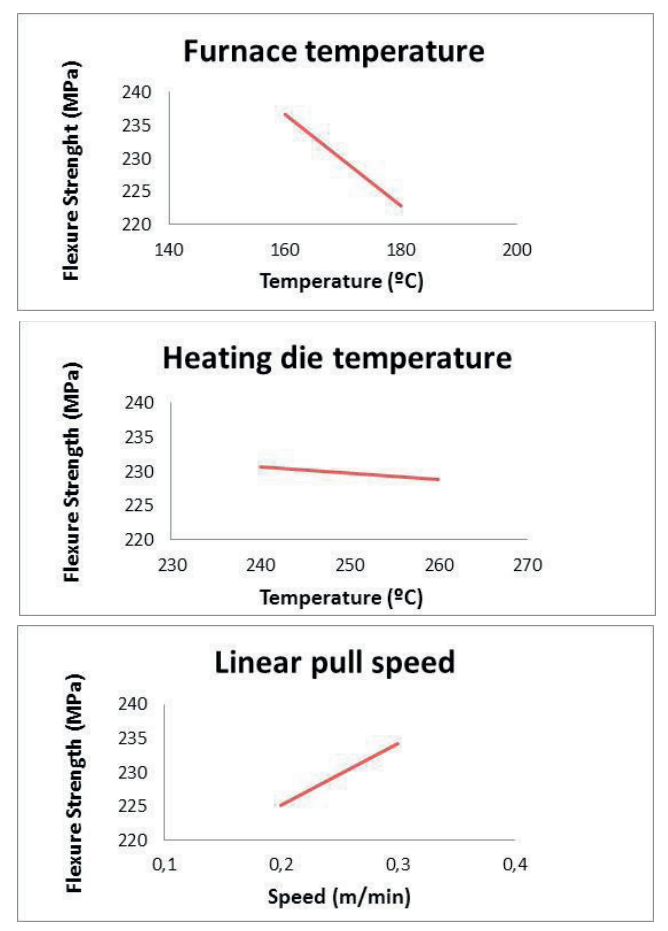

Fig. 7. Variation of the flexural strength with the selected processing parameters.
Finally, towpregs with additive were also pultruded into bars using the condition that optimizes both flexural properties and two more conditions (see Table $6)$.

Table 6. Flexural properties of towpregs with additive processed by pultrusion

\begin{tabular}{ccccccc}
\hline & \multicolumn{3}{c}{ Processing variables } & & \multicolumn{2}{c}{ Flexural properties } \\
\cline { 2 - 3 } Exper. & $\begin{array}{c}\text { Furnace } \\
\text { temperature } \\
\left({ }^{\circ} \mathbf{C}\right)\end{array}$ & $\begin{array}{c}\text { Heating die } \\
\text { temperature }\end{array}$ & $\begin{array}{c}\text { Linear } \\
\text { pulling speed } \\
(\mathbf{m} / \mathbf{m i n})\end{array}$ & & $\begin{array}{c}\text { Flexural } \\
\text { modulus } \\
(\mathbf{G P a})\end{array}$ & $\begin{array}{c}\text { Flexural } \\
\text { strength } \\
(\mathbf{G P a})\end{array}$ \\
\hline 1 & 160 & 260 & 0,2 & & $229.0 \pm 7.3$ & $87.6 \pm 1,3$ \\
2 & 160 & 240 & 0,2 & & $191.7 \pm 7.8$ & $70.4 \pm 2.8$ \\
3 & 160 & 240 & 0,3 & & $237.4 \pm 11.8$ & $80.5 \pm 2.6$ \\
\hline
\end{tabular}

Table 7 shows the obtained results from flexural tests using towpreg pultruded bars with and without additive of maleic anhydride. It is possible to conclude that use of additive had no significant influence on the flexural properties.

Table 7. Flexural test results on towpreg bars with and without additive

\begin{tabular}{|c|c|c|c|c|c|}
\hline \multirow{2}{*}{$\begin{array}{l}\text { Processing } \\
\text { parameters }\end{array}$} & & \multicolumn{2}{|c|}{$\begin{array}{c}\text { Flexural modulus } \\
\text { (GPa) }\end{array}$} & \multicolumn{2}{|c|}{$\begin{array}{c}\text { Flexural strenght } \\
\text { (GPa) }\end{array}$} \\
\hline & & $\begin{array}{l}\text { Without } \\
\text { additive }\end{array}$ & $\begin{array}{c}\text { With } \\
\text { additive }\end{array}$ & $\begin{array}{l}\text { Without } \\
\text { additive }\end{array}$ & $\begin{array}{c}\text { With } \\
\text { additive }\end{array}$ \\
\hline $\begin{array}{l}\text { Furnace } \\
\text { temperature }\left({ }^{\circ} \mathrm{C}\right)\end{array}$ & 160 & \multirow{3}{*}{$90.1 \pm 0.4$} & \multirow{3}{*}{$87.6 \pm 1.3$} & \multirow{3}{*}{$241.2 \pm 1.6$} & \multirow{3}{*}{$229.0 \pm 7.3$} \\
\hline $\begin{array}{l}\text { Heating die } \\
\text { temperature }\left({ }^{\circ} \mathrm{C}\right)\end{array}$ & 260 & & & & \\
\hline $\begin{array}{l}\text { Linear pulling } \\
\text { speed }(\mathrm{m} / \mathrm{min})\end{array}$ & 0,2 & & & & \\
\hline
\end{tabular}

\subsubsection{Pre-consolidate tapes processing}

CF/PP PCT were processed into composite bar profiles using the already mentioned pultrusion equipment die and the following typical operating conditions:

-Furnace temperature $\left(160^{\circ} \mathrm{C}\right)$;

-Heating die temperature $\left(260^{\circ} \mathrm{C}\right)$;

-Linear pull-speed $(0.2 \mathrm{~m} / \mathrm{min})$.

\subsection{Testing}

\subsubsection{Towpreg testing}

Towpregs were characterized by scanning electron microscopy (SEM) and visual analysis.

Several CF/PP produced towpreg samples were analysed under a Nova NanoSEM 200 Scanning Electron Microscope to evaluate the adhesion of the 
polymer powder to the fibers and its distribution. Figure 8 show SEM micrographs of towpreg samples. As may be seen, a reasonable degree of adhesion between the carbon fibers and the polymer powder particles was obtained. Also, the polymer particles distribution on the fibers can be considered sufficient and eventually improved.
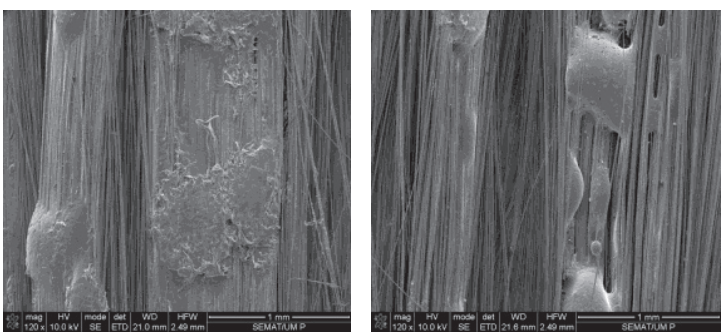

Fig. 8. Typical towpreg SEM micrographs (magnification of 120×).

\subsubsection{Composites testing}

Samples of pultruded bars were submitted to flexural, tensile, interlaminar and calcination tests according to the ISO standards 14125, 527, 14130 and 1172, respectively, and had their cross-sections studied under optical Microscopy (see Fig. 9). PCT's were also submitted to the same tests.
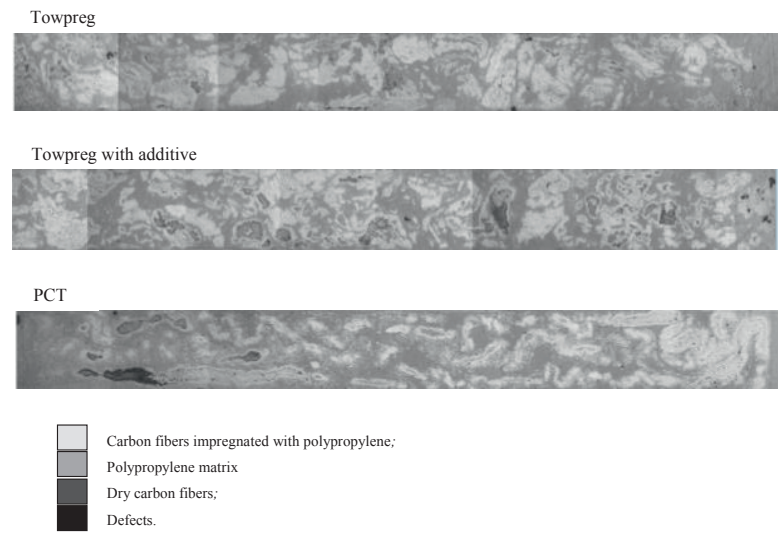

Fig. 9. Optical micrographs of the pultruded profiles cross-section (magnification of $8.75 \times$ ).

The obtained mechanical properties were compared to the theoretical ones predicted by using the Rule of Mixtures (ROM).

\subsubsection{Test results}

Table 8 summarizes all experimentally obtained test results.

Table 8. Composite mechanical test results

\begin{tabular}{|c|c|c|c|c|c|}
\hline \multirow[b]{2}{*}{ Test Type } & \multirow{2}{*}{\multicolumn{2}{|c|}{ Property }} & \multicolumn{3}{|c|}{ Pultrusion } \\
\hline & & & \multirow{2}{*}{$\begin{array}{c}\text { Towpreg } \\
90.1 \pm 0.4\end{array}$} & \multirow{2}{*}{$\begin{array}{c}\begin{array}{c}\text { Towpreg with } \\
\text { addtive }\end{array} \\
87.6 \pm 1.3\end{array}$} & \multirow{2}{*}{$\begin{array}{c}\boldsymbol{P C T} \\
37.7 \pm 2.2\end{array}$} \\
\hline \multirow{6}{*}{ Flexural } & \multirow{2}{*}{$\begin{array}{c}\text { Flexure } \\
\text { Modulus } \\
\text { (GPa) }\end{array}$} & Experimental & & & \\
\hline & & Theoretical & 85.7 & 85.5 & 54.0 \\
\hline & \multicolumn{2}{|c|}{$\begin{array}{l}\text { Flexure Modulus / Fiber } \\
\text { volume fraction }(\mathrm{GPa})\end{array}$} & $178.1 \pm 0.8$ & $173.5 \pm 2.6$ & $118.2 \pm 6.9$ \\
\hline & \multirow{2}{*}{$\begin{array}{l}\text { Flexure } \\
\text { Strength } \\
(\mathrm{MPa})\end{array}$} & Experimental & $241.2 \pm 1.6$ & $229.0 \pm 7.3$ & $158.7 \pm 4.2$ \\
\hline & & Theoretical & 1311.0 & 1308.4 & 825.8 \\
\hline & \multicolumn{2}{|c|}{$\begin{array}{l}\text { Flexure Strength / Fiber } \\
\text { volume fraction }(\mathrm{MPa})\end{array}$} & $476.7 \pm 3.2$ & $453.5 \pm 14.5$ & $497.5 \pm 13.2$ \\
\hline \multirow{3}{*}{ Tensile } & \multirow{2}{*}{$\begin{array}{c}\text { Tensile } \\
\text { Modulus } \\
(\mathrm{GPa})\end{array}$} & Experimental & $110.6 \pm 5.9$ & $106.1 \pm 6.3$ & $63.5 \pm 4.3$ \\
\hline & & Theoretical & 85.7 & 85.5 & 54.0 \\
\hline & \multicolumn{2}{|c|}{$\begin{array}{l}\text { Tensile Modulus / Fiber } \\
\text { volume fraction }(\mathrm{GPa})\end{array}$} & $218.6 \pm 11.7$ & $210.1 \pm 12.5$ & $199.1 \pm 13.5$ \\
\hline $\begin{array}{l}\text { Inter- } \\
\text { laminar } \\
\text { Shear } \\
\end{array}$ & \multicolumn{2}{|c|}{$\begin{array}{l}\text { Interlaminar Shear Strength } \\
(\mathrm{MPa})\end{array}$} & $12.3 \pm 0.3$ & $13.0 \pm 0.4$ & $14.0 \pm 0.2$ \\
\hline \multicolumn{3}{|c|}{ Fiber volume fraction (\%) } & 50.6 & 50.5 & 31.9 \\
\hline
\end{tabular}

The tensile strength and modulus of the CF/PP plates, were predicted from the fiber and polymer properties using the well-known law of mixtures.

As can be seen from Table 8, experimental strength results are lower than those theoretically predicted. The experimental moduli obtained are in good agreement with the theoretical ones.

\section{Conclusions}

Obtained results allow concluding that all the pre-impregnated products studied in this work presented enough good properties for being employed in the major commercial engineering structural applications.

Composites processed from the PCTs demonstrated to have better mechanical strength than those produced from towpregs.

As can be seen from the Fig. 9, all profiles have a reasonable distribution of the reinforcing fibers over the cross-sections.

However, large differences in impregnation quality occur between the different samples that are likely to be related, directly, to the impregnation state of the semi-finished used on pultrusion. It may be seen that the impregnation quality of the PCT composite samples is good, presenting almost all fibers completely surrounded ('wet-out') by the polymer. 
Only a few large dry spots were observed. This is most likely due to the good degree of impregnation already achieved in the PCT raw-material tape prior to the pultrusion step.

The samples of towpreg with additive show a higher quantity of dry zones than the ones without additive.

Finally, it may be noted that any of composites made from the towpregs and PCTs reached failure in the interlaminar shear tests. This fact reveals the high degree of ductility exhibited by these materials which may be relevant for many applications. Thus, the interlaminar shear strength results shown in Table 8 correspond to maximum force applied in the test.

The tests made using a proprietary pultrusion equipment already allow concluding being possible to produce in good conditions profiles from almost all commercial available thermoplastic matrix pre-impregnated raw-materials using pull speeds of $0.3 \mathrm{~m} / \mathrm{min}$.

It was possible to optimize the production of pultruded profiles and towpregs, through the use of Taguchi method, achieving optimal conditions.

The addition of the compatibilizing agent ( $1 \%$ maleic anhydride) did not improve the polymer mass content in towpregs and the mechanical properties on the final composites.

\section{References}

[1] S. Mazumdar, High Performance Composites, (May 2012).

[2] G. Bechtold, S. Wiedmer, K. Friedrich, J. Thermoplast. Compos. Mater. 15, 443 (2002).

[3] J.F. Silva, J.P. Nunes, F.W. Van-Hattum, C.A. Bernardo and A.T. Marques, Improving Low-Cost Continuous Fibre
Thermoplastic Composites by Tailoring Fibre-Matrix Adhesion, International Workshop on Thermoplastic Matrix Composites, 11-12 September, Gallipoli, Italy, 2003.

[4] T. Åström, A. Carlsson, Compos. Part A: Appl. Sci. Manuf. 29A, 585 (1998).

[5] A.H. Miller, N. Dodds, J.M. Hale, A.G. Gibson, Compos. Part A: Appl. Sci. Manuf., 29A, 773 (1998).

[6] J.P. Nunes, J.F. Silva, F.W.J. van Hattum, C.A. Bernardo, A.T. Marques, A.M. Brito, A.S. Pouzada, Production of Thermoplastic Towpregs and Towpreg-based Composites in Polymer Composites - From Nano- to acroScale, K. Friedrich, S. Fakirov, Z. Zhang (Eds), Kluwer Academic Publishers, 2005.

[7] K. Ramani, H. Borgaonkar, C. Hoyle, Compos. Manuf. 6, 35 (1995).

[8] G. Sala, D. Cutolo, Compos. Part A: Appl. Sci. Manuf. 28A, 637 (1997).

[9] D. Purnima, S.N. Maiti, A.K. Gupta, J. Appl. Polym. Sci. 102, 5528 (2006)

[10] M. Oever, T. Peijs, Compos. Part A: Appl. Sci. Manuf. 29, 227 (1998).

[11] H.-S. Kim, B.-H. Lee, S.-W. Choi, S. Kim, H.-J. Kim, Compos. Part A: Appl. Sci. Manuf. 38, 1473 (2007).

[12] A. Janevski, G. Bogoeva-Gaceva, E. Mader, J. Adhes. Sci. Technol. 14, 363 (2000).

[13] J.P. Nunes, J.F. Silva, A.T. Marques, Using additives to improve the properties of composites made from towpregs, Proceedings of ANTEC'05, Boston, USA, May 1-5, 2005.

[14] R.F. Silva, J.F. Silva, J.P. Nunes, C.A. Bernardo, A.T. Marques, Mater. Science Forum 587-588, 246 (2008).

[15] R. Fazenda, J.F. Silva, J.P. Nunes, C.A. Bernardo, New Coating Equipment To Produce Long Fibre Thermoplastic Matrix Towpregs at Industrial Scale, Proceedings of ANTEC'07, Cincinnati, Ohio/USA, May 6-10, 2007.

[16] P.J. Novo, J.F. Silva, J.P. Nunes, F.W.J. van Hattum, A.T. Marques, Development of a new pultrusion equipment to manufacture thermoplastic matrix composite profiles, ECCM 15, June 24-28, Venice, Italy, 2012.

[17] J.P. Nunes, J.F. Silva, P.J. Novo, Adv. Polym. Technol. 32, E302 (2013). 